\title{
Graduate and Undergraduate Horticultural Enrollment and Programs in U.S. Institutions
}

\author{
Gary A. Couvillon \\ Department of Horticulture, University of Georgia, Athens, GA 30602
}

Accurate information is lacking about undergraduate and graduate horticultural enrollments in the United States, including the composition of each enrollment category, the scope and nature of the programs offered, enrollment by specialization, and enrollment trends. An accurate comprehensive study is needed for many reasons: 1) to provide a benchmark to follow future trends, 2) to provide a data base to answer inquiries about programs and enrollment, 3) to assist horticulture departments with information for budget planning and projecting facility needs, and 4) to provide information for minority graduate student and faculty recruitment.

A recent article in Money magazine (Morris, 1990) included horticulture as one of the 25 most promising careers for the 1990s. Yet Urbano (1990) reports that horticultural undergraduate enrollment is $44 \%$ of the highpoint of 1975-76. There is a need to assess current graduate and undergraduate enrollments and future needs. Recent surveys by Urbano (1990) and Carter et al. (1990) are incomplete or based on estimations and extrapolations and thus may be inaccurate. The Education Division of ASHS assumed the responsibility of collecting enrollment information from degree-granting institutions so that a benchmark could be established that could be updated annually.

The survey. There are 136 North American institutions, including two Puerto Rican and 19 Canadian, that grant baccalaureate and/or graduate degrees in horticulture (Childers, 1989). Childers (1989) did not include institutions in The Virgin Islands, Washington, D. C., or Guam. For the purpose of this survey, three categories of U.S institutions that offer horticultural programs were surveyed. One group consists of 50 institutions with land grant status (excluding the Universities of the District of Columbia, Guam, Puerto Rico, and Virgin Islands) that produce a high percentage of the horticultural undergraduates, MS graduates, and all of the $\mathrm{PhD}$ graduates. Two land grant institutions, the Universities of Alaska and Wyoming, do not offer majors or degrees in horticulture. A second category consists of 16 (including Tuskegee Univ.) 1890 institutions, 15 of which have horticulture, or plant science programs. Langston Univ., the 1890 school of Oklahoma, recently discontinued its horticulture program. The final group of 50 institutions has primarily under-

Received for publication 10 Aug. 1990. graduate programs, although a few offer the MS degree in horticulture.

The graduate and undergraduate horticulture programs are administered by departments that have varying titles. Of the 73 institutions reporting, 31 contained only horpomology, olericulture, or ornamental horticulture, in the departmental title; eight had horticulture and another discipline in the title; forestry appeared with horticulture in four; five were horticulture and landscape architecture or environmental design departments; horticulture or a horticultural subdiscipline did not appear in 29 of the departmental titles. Of the reporting land grant institutions (46 institutions totaling 58 departments), 29 departments were horticulture departments only (including pomology, olergrant institutions having more than one horticultural department include Florida (3), California (4), Cornell (3), and Tennessee (2) (pomology and olericulture are in a plant and soil science department). An additional six departments contained horticulture in the departmental title (four with forestry and three with landscape architecture or environmental design). Horticulture did not appear in the titles of 12 departments (these were mostly crop or plant science departments in land grant institutions).

The program and enrollment data that follow represent a fairly accurate estimate of the graduate horticultural enrollment in the United States, in that $91.5 \%$ (54 of 59) of the horticultural departments of land grant institutions offering graduate programs in horticulture reported (four U.S. land grant ticulture or a horticultural sub-area, such as iculture, and ornamental horticulture). Land

institutions and one horticulture department of a multidepartmental institution did not report). Only 21 of 50 four-year non-land grant and 1890 institutions and one of 19 Canadian institutions that have horticultural programs responded. The poor response by these institutions should not affect the accuracy of the undergraduate enrollment data reported. Several of the institutions with an undergraduate enrollment of $\geq 100$ in horticulture were in the reporting group and the remaining had enrollments that ranged from 25 to eight undergraduate students. Also, many of the 4year non-land grant institutions do not separate majors into the various plant science categories, since they offer a major in plant science only. Also, the data presented show higher enrollments than reported by Carter et al. (1990), which indicates a more thorough and accurate analysis of horticultural enrollment in the U.S. institutions in the present report.

Programs offered. Horticulture departments offered 29 undergraduate majors, concentrations, and/or options from which a student could select (Table 1). The most frequently offered programs were ornamental horticulture, olericulture, pomology, floriculture, and turf management. Many other areas of study, offered as separate programs, appeared with a low degree of frequency and were closely allied to one of the most common programs.

Graduate programs span disciplines and involve basic as well as applied research. The departments had graduate programs in all of the horticultural commodity areas, with graduate research in genetics and plant breeding, physiology (including stress phys-

Table 1. Undergraduate programs offered by horticultural departments in the United States, 1990.

\begin{tabular}{lclc}
\hline \hline Area of study & $\begin{array}{c}\text { Departments } \\
\text { (no.) }\end{array}$ & \multicolumn{1}{c}{ Area of study } & $\begin{array}{c}\text { Departments } \\
\text { (no.) }\end{array}$ \\
\hline Ornamental & 46 & Horticulture therapy & 1 \\
Olericulture & 27 & Landscape contracting & 1 \\
Pomology & 26 & Landscape industry & 1 \\
Floriculture & 25 & Landscape maintenance & 1 \\
Turf mgt. & 22 & Nursery mgt. & 1 \\
Landscape design & 10 & Plant physiology & 1 \\
Science & 3 & Plant propagation & 1 \\
Botany & 2 & Preforestry & 1 \\
Postharvest & 2 & Production business & 1 \\
Biology & 1 & Public horticulture & 1 \\
Biotechnology & 1 & Teaching and extension & 1 \\
Environmental & 1 & Urban forestry & 1 \\
Floral shop mgt. & 1 & Urban horticulture & 1 \\
Garden center mgt. & 1 & Viticulture & 1 \\
Greenhouse met. & 1 & &
\end{tabular}


iology), biotechnology (including tissue culture), agricultural weather (climatology), and postharvest physiology.

Undergraduate enrollment. The enrollment survey (Table 2) indicates 4018 undergraduate horticultural majors enrolled in programs leading to a baccalaureate degree in 1990 . Of these, $56 \%$ were in ornamental horticulture, $8.6 \%$ in floriculture, $3.7 \%$ in pomology, $2.6 \%$ in olericulture, $6.8 \%$ in turf management, and $23 \%$ in other horticultural specialties (e. g., postharvest, tissue culture, landscape horticulture). Of the total number (including Canada) of domestic students enrolled, $61 \%$ are male and $39 \%$ are female. Two percent of the total enrollment are from foreign countries. The enrollment of female students in horticultural undergraduate programs $(39 \%)$ is $11 \%$ higher than that reported for plant science programs $(28 \%)$ at U.S. institutions (Carter et al., 1990). Only $4.8 \%$ of the total number of students enrolled in undergraduate horticultural programs belong to domestic minority groups (4.2\% male and $6.1 \%$ female). These percentages are within the range of minority enrollment at most predominately white institutions (3\% to $8 \%$ ) and are $0.8 \%$ higher than that reported (Carter et al., 1990) for plant science programs in colleges of agriculture of U.S. universities. Of the total horticultural undergraduate minority enrollment, $39 \%$ are at the Univ. of Hawaii (Honolulu and Hilo campuses) and $8 \%$ at the two reporting 1890 institutions.

Undergraduate enrollment is highest in ornamental horticulture and lowest in pomology and olericulture (Fig. 1). The horticultural specialty category with the second highest enrollment total was a category listed as "other", which included all specialties other than ornamental, floriculture, pomology, olericulture, or turf management, many of which were closely related to ornamental horticulture.

The trends reported for the 5 years of 19851990 show a relatively stable horticultural enrollment (Table 3). Enrollments in horticulture seem to have bottomed in 1987-88 and are on the rebound. Morris (1990) reported projected growth in the 1990s in landscape horticulture, plant growing and retailing, and landscape maintenance (includes golf course management). Trained personnel with the BS degree will be needed to fill these positions. Horticulture programs are unable to fill the current request for trained personnel; thus, without drastically increased undergraduate enrollments, a more severe shortage of trained horticulturists during the 1990 s is a certainty. Although a high percentage of the undergraduate enrollment is in the ornamental horticulture subdiscipline, which is where the demand projected by Morris (1990) is to occur, it appears that an intensive effort should be made to recruit students into horticultural specialties in addition to ornamental horticulture to maintain a viable horticultural industry and to supply the demand in areas such as turf management. Much time and many resources have

Table 2. Undergraduate and graduate enrollments in horticultural programs for 1989-90.

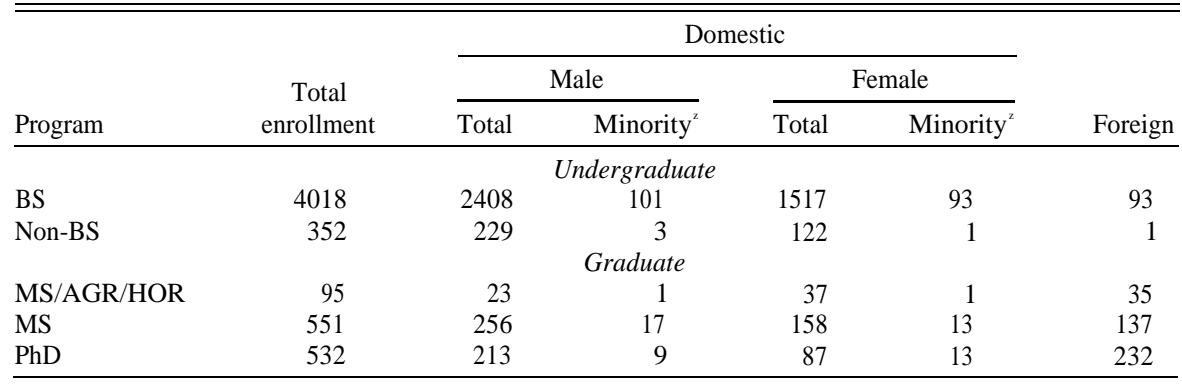

${ }^{2}$ All minorities reported are domestic only and are included in the total for each sex.

Table 3. Enrollment trends in horticultural programs, 1985-90.

\begin{tabular}{lccccr}
\hline \hline & \multicolumn{5}{c}{ Enrollment } \\
\cline { 2 - 6 } Program & $1985-86$ & $1986-87$ & $1987-88$ & $1988-89$ & $1989-90$ \\
\hline BS & 3980 & 3775 & 3650 & 3704 & 4018 \\
Non-BS & 409 & 412 & 416 & 410 & 352 \\
MS/AGR/HOR & 74 & 68 & 82 & 67 & 93 \\
MS & 563 & 507 & 553 & 535 & 544 \\
PhD & 471 & 517 & 557 & 567 & 520 \\
\hline
\end{tabular}

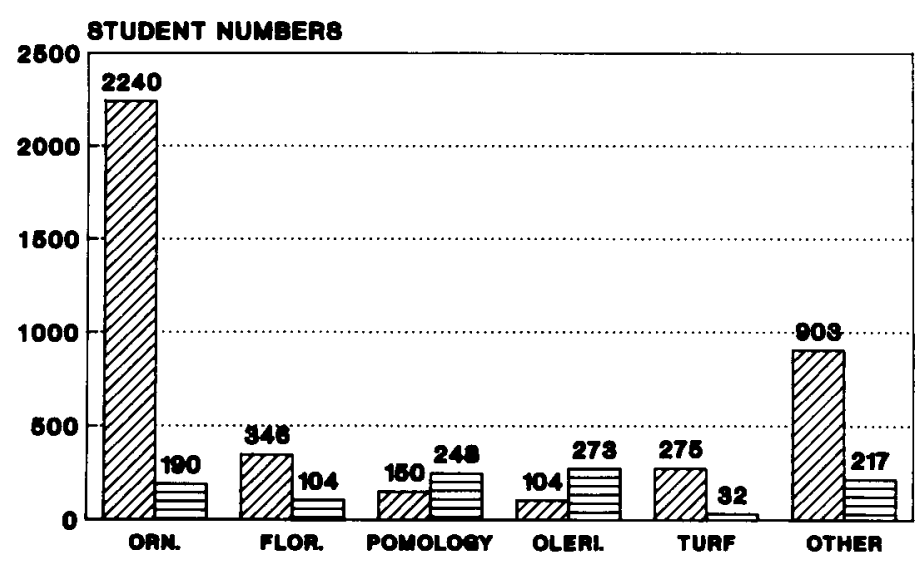

Fig. 1. Distribution of horticulture undergraduate ( ization. "Other" includes: postharvest physiology and technology, biotechnology, and others (see Table 1).

been invested by horticulture departments in an effort to increase majors in all specializations of the profession, but most have met with limited success. Possibly, the recruitment effort has been of some benefit as evidenced by a stabilized rather than decreasing enrollment, as experienced by many other agricultural disciplines. Articles that promote the profession, such as appeared in the magazine Money (Morris, 1990), should help the recruitment effort. Although many factors enter into our inability to attract qualified students into the profession, the low entry salary provided for graduates with the BS degree in horticulture is the greatest determent to student recruitment (Morris, 1990; Shemin, 1989; Smith, 1990; Urbane, 1990). Morris (1990) noted that of the 25 projected growth careers of the 1990s, the expected earnings of a horticulturist with experience and a BS degree ranked 24th. She reported a range of $\$ 30,000$ to $\$ 65,000$ or more as the expected annual salary for a horticulturist, while VerMeulen (1990) cited \$45,000 as the annual income for a 30-year-old, fourth generation raisin grower in California. However, both amounts cited by these authors are obviously nonentry. Unger (1990) found entry level salaries for BS graduates to range from $\$ 33,380$ (chemical engineers) to $\$ 18,157$ (home economists). Entry level salaries for horticulturists must increase to the midrange $(\$ 25,000-\$ 27,000)$ to be competitive.

Nonbaccalaureate degree granting programs. Eight land grant and three non-land grant institutions have nonbaccalaureate undergraduate programs with a total enrollment of 352 students (Table 3 ). In these programs, $\approx 67 \%$ are males, $33 \%$ females; $0.2 \%$ are foreign students. Domestic minority males and females represent $0.9 \%$ and $0.2 \%$, respectively, of the students in the programs. Carter et al. (1990) reported 457 students enrolled in 2-year horticultural programs during Fall 1989, while our study found only 410 for the same year. These programs are professional in nature, generally 2 years long, and grant a certificate and/or associate degree upon fulfillment of the program requirements. Generally, courses specifically 
designed for these programs constitute the curriculum. The enrollment trends (Table 3) for the 5 years studied ranged from 352 (198990) to 416 (1987-88).

Graduate enrollment. Institutions surveyed reported 1178 students enrolled in horticultural graduate programs (Table 2). Of this total, $8.1 \%$ of the students were enrolled in Master of Agriculture/Horticulture (professional degree) programs, 47\% were enrolled in MS programs, and $44.9 \%$ in $\mathrm{PhD}$ programs. These totals as well as those for 1989 (Table 3) are considerably higher than that reported for 1989 by Carter et al. (1990) (432 MS, $353 \mathrm{PhD}$ ) for horticultural programs at U.S. institutions. They did not report on Master of Agriculture/Horticulture program enrollment. Enrollment by area of specialization for the MS and $\mathrm{PhD}$ programs were nearly the reverse of that of the undergraduate program (Fig. 1). Graduate students specializing in olericulture constituted the largest specialization group $(25.5 \%$ of total graduate enrollment) followed by pomology $(23.13 \%)$, other $(20.4 \%)$, ornamental horticulture $(18.47 \%)$, floriculture $(9.7 \%)$, and turf management (3.3\%). Employment opportunities for graduates with the BS degree with a specialization in ornamental horticulture or turf management are greater than for BS graduates with specialization in olericulture or pomology. Most graduates with specialization in ornamental horticulture, floriculture, or turf management enter the work force following the BS degree. Employment opportunities for students with an olericulture or pomology specialization are greater after a graduate degree.

Master of Agriculture/Horticulture programs. Eighteen departments offered a Master of Agriculture/Horticulture degree. The enrollment in this program (Table 2) was $38 \%$ male, $62 \%$ female; $37 \%$ were foreign students. The domestic minority enrollment was $1(0.85 \%)$ male and $1(0.85 \%)$ female. Enrollment trends (Table 3 ) showed that enrollment levels within these programs for 1985-1990 have remained relatively steady and ranged from a high of 93 students in
1989-90 to a low of 67 in 1988-89.

MS programs. Horticulture departments reported 551 students (Table 2) enrolled in MS programs. Of these, $62 \%$ were male, $38 \%$ female, and $9 \%$ foreign. Seventeen students $(3.1 \%)$ were domestic male minorities and $13(2.4 \%)$ were domestic female minorities. Enrollment trends (Table 3 ) in the MS programs show a high of 563 students enrolled in $1985-86$ to a low of 507 students in 1986-87.

PhD programs. A total of $532 \mathrm{PhD}$ candidates (Table 2) were enrolled in programs of those departments reporting. Seven of the 52 departments of land grant institutions had no $\mathrm{PhD}$ degree program in horticulture and a $\mathrm{PhD}$ program did not exist at any non-land grant institutions that reported. About $71 \%$ of the $\mathrm{PhD}$ enrollment was male, $29 \%$ female, and $43 \%$ foreign students. Twenty-two students $(4.2 \%)$ enrolled were domestic minorities of which $9(1.7 \%)$ were male and $13(2.5 \%)$ female. Enrollment trends (Table 3 ) for the 5 years studied showed that enrollment ranged from a high of $567 \mathrm{PhD}$ students in 1988-89 to a low of 471 in 198586.

Conclusions. There seems to be a strong need to increase enrollments in all horticulture programs if the requirements of the profession are to be met in the 1990s. The projected growth is in the broad area of ornamental horticulture, which presently contains the greatest percentage of horticulture majors. The current number of graduates in ornamental horticulture is insufficient to maintain current needs, and this deficit will increase if enrollment levels do not increase. Undergraduate enrollment in nonornamental programs is low and must be increased if a sufficient number of graduates is to be produced to provide the necessary number of students for graduate programs and the BS graduate needs of the profession. Of particular interest is the domestic minority enrollment in all horticultural programs. The small domestic minority pool (30 students at the MS level and $22 \mathrm{PhD}$ candidates) will provide only a small portion of the students needed to 1) significantly affect the minority enrollment of horticultural $\mathrm{PhD}$ programs and 2) fill minority faculty positions as mandated by the current Affirmative Action program of the U.S. government with horticulturists with the $\mathrm{PhD}$. Also, the small minority enrollment in undergraduate programs will not provide a sufficient number of students to feed graduate programs with domestic minorities. Carter et al. (1990) found that general plant science graduate programs contained a minority enrollment of $9.8 \%$, which is about double that of horticulture. Moreover, Carter et al. (1990) received a high response from institutions with predominantly black enrollment that have agricultural programs and/or they extrapolated data, while we received a very low percentage of response from 1890 institutions and our data represent actual numbers reported. An intensive recruitment effort should be made at the undergraduate level to increase enrollments, with special emphasis on minorities. Success in recruitment will depend heavily on increases in the entry level salaries for horticultural professionals at the BS level.

\section{Literature Cited}

Carter, M., D. Shippy, W. Sleight, and J. White. 1990. Fall 1990. Enrollment in NASULGC Colleges of Agriculture. Natl. Assn. State Univ. and Land Grant Colleges, Washington, D.C.

Childers, N.F. 1989. Educational institutions offering horticulture and/or landscape architecture in the United States and Canada. HortScience 24(2):211-217.

Morris, M. 1990. Work in the '90s: 15 fast-track careers. Money 19(6): 108-126.

Shemin, E. 1989. Where do we go from here? Nursery Business 34(8):14-50.

Smith, S.L. 1990. Top of the class. Amer. Nurseryman 171(1):86-93.

Unger, H. 1990. Grads who want jobs can't be too picky. Atlanta Journal and Constitution, 3 June. p. H-1-H-3.

Urbane, C.C. 1990. Head of the class: Professorial view. Amer. Nurserymanm 171(1):74-84.

VerMeulen, M. 1990. What people earn. Parade Magazine, 17 June. p. 4-7. 